\title{
Food Density and Rate of Feeding Larvae of Anchovy and Sardine in Patchy Distribution
}

\author{
Katsumi Matsushita, ${ }^{*}$ Makoto Shimizu, ${ }^{*}$ and Yukio Nose* \\ (Accepted November 30, 1987)
}

\begin{abstract}
The feeding conditions of larvae of anchovy and sardine in patchy distribution were surveyed in order to know the mechanisms of larval survival in the sea. The larvae and plankters were continuously collected crossing their patches at sea surface (the length of one transect segment was $0.75-3 \mathrm{~km}$ ). The patches of larvae and plankters detected were caused by oceanographic structure (i.e., front and upwelling) and were transported with eddy generated behind island by ocean current.

The guts of the larvae collected were examined under microscope in order to know "feeding" or "non-feeding", and the rate of feeding larvae in each segment was calculated. The rate of feeding larvae did not show any recognizable relationship with the density of their food organisms of each segment. The rate of feeding larvae was inversely correlated to the density of larvae of each segment. The rate of feeding larvae over $20 \mathrm{~mm}$ is high and under $5 \mathrm{~mm}$ extremely low. From these results, it is considered that the micro-patch of food organisms and the passing speed of food organisms in the visual field of larva, which is caused by turbulence of water, are possibly important in the larval feeding.
\end{abstract}

The study on mechanism of larval survival makes an important part of fish stock study, and the study is now focused on how to explain the huge fluctuation in recruitment which can not be ascribed to the size of the spawning stock. Hjort ${ }^{12}$ suggested that a year class strength of stock is most probably determined by the mortality at the earliest larval feeding stage, and the mortality is dependent upon the food density when they first begin to feed. Also, it was reported from many rearing experiments that the food density in larval surroundings is a very important factor for larval survival. ${ }^{2-4)}$ Lasker, ${ }^{5,8)}$ however, reported that the density of food organisms is extremely low in the sea comparing to the threshold food density estimated rearing experiments. This is especially so in offshore waters, main spawning area for pelagic fish. Considering these matters, Shelbourne, ${ }^{7)}$ O'Connel and Raymond, ${ }^{2)}$ Hunter and Thomas, ${ }^{8)}$ and Laurence ${ }^{\theta)}$ emphasized the possible importance of patchy distribution of the food organisms for survival of larvae.

Also, it has been well known that the eggs and larvae of marine fish and their food organisms are distributed in patches of various scales. ${ }^{10-10)}$ Under these situations, it is expected that the larval encounter rate with the food organisms is greatly varied in the sea.

In the case of fish larva with poor swimming ability, this encounter rate may greatly influence the feeding success. From this view point, it is considered important to survey not only the geographical distribution with fixed points observations but also the structures of patchiness of larvae and food organisms simultaneously. It must be examined by these surveys how the oceanographic structures influence on the relationship of larval feeding condition and food organism density.

\section{Materials and Methods}

\section{Field Survey}

The surveys were carried out at the KT-75-9 and the KT-79-3 cruises of the R/V "Tansei-maru" of the Ocean Research Institute of University of Tokyo.

The locations of surveys and the other data, i.e., sampling day and time, sampling number, towing length of one sampling, etc., are shown in Table 1. The surveys were carried out in the daytime since it was considered that the larvae are not able to feed in the darkness. ${ }^{17}{ }^{18}$ ) The survey lines and oceanographic conditions are

* Faculty of Agriculture, The University of Tokyo, Yayoi, Bunkyo, Tokyo 113, Japan. (松下克已, 洋水 部成, 能勢幸雄: 東京大学農学部水産学科). 
Table 1. Sampling conditions of the continuous field surveys along the transect lines

\begin{tabular}{|c|c|c|c|c|c|}
\hline Cruise & Date and time & Locality & $\begin{array}{l}\text { Length } \\
\text { of a } \\
\text { segment } \\
(\mathrm{km})\end{array}$ & $\begin{array}{l}\text { Number } \\
\text { of } \\
\text { segment }\end{array}$ & $\begin{array}{l}\text { Average volume } \\
\text { of water } \\
\text { for a segment }(l) \\
\text { (Mean } \pm \text { S.D.) }\end{array}$ \\
\hline KT $-75-9$ & $\begin{array}{l}17 \text { Jul. '75 } \\
13: 50-19: 20\end{array}$ & $\begin{array}{r}34^{\circ} 10.6^{\prime} \mathrm{N} \\
137^{\circ} 04.0^{\prime} \mathrm{E} \\
34^{\circ} 20.0^{\prime} \mathrm{N} \\
138^{\circ} 05.0^{\prime} \mathrm{E}\end{array}$ & 3 & 32 & $1210 \pm 62.2$ \\
\hline KT-79-3 & $\begin{array}{l}10 \text { Mar. }{ }^{' 79} \\
8: 20-13: 55\end{array}$ & $\begin{array}{r}34^{\circ} 01.8^{\prime} \mathrm{N} \\
139^{\circ} 28.4^{\prime} \mathrm{E} \\
\\
34^{\circ} 35.0^{\prime} \mathrm{N} \\
138^{\circ} 58.1^{\prime} \mathrm{E}\end{array}$ & $\begin{array}{l}1.5 \\
(0.75 \\
\text { in part) }\end{array}$ & 72 & $596 \pm 24.1$ \\
\hline
\end{tabular}

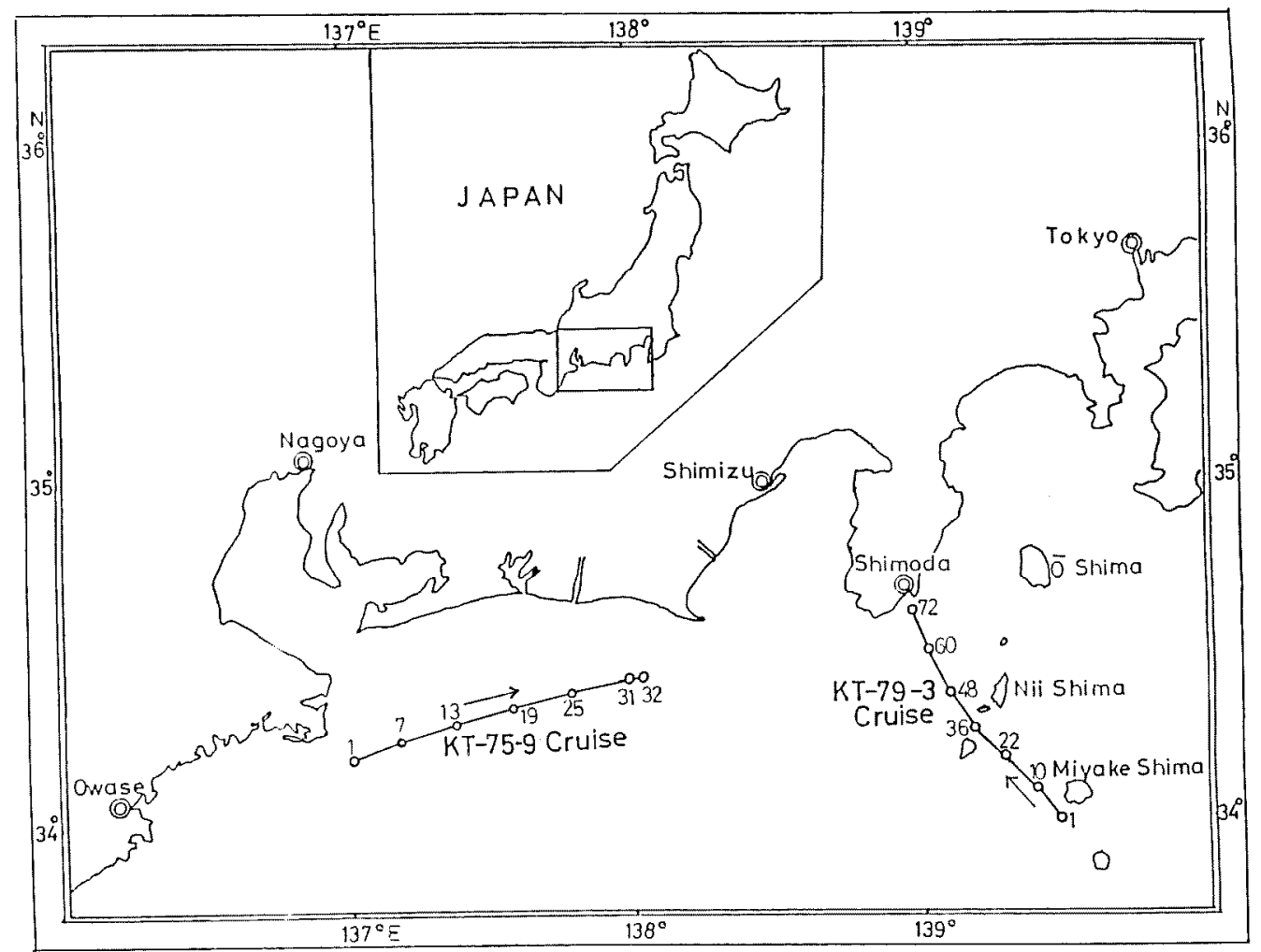

Fig. 1. The map showing the locations of transect lines of continuous field surveys. Open circles indicate the locations where the ship position was measured hourly.

The figures beside the open circles are segment number.

shown in Fig. 1.

Fish larvae and the food organisms were collected at 0-60 cm layer of the sea surface with a high speed continuous sampler newly devised. ${ }^{19)}$ The sea water was raised up to ship board by water pressure which was produced at the mouth of the sampler by its towing in the sea water. By filtering the sea water, it was possible to collect quantitatively and continuously the eggs and larvae and the other plankters.

The samplings were continuously carried out by alternating two filtering nets with every 10 minutes at the KT-75-9 cruise and 5 minutes (sometimes $2.5 \mathrm{~min}$. at areas of dense patch of the larvae (segments No. 31-35)) at the KT-79-3 cruise. As the ship speed was about $10 \mathrm{kt}$, the length of one 

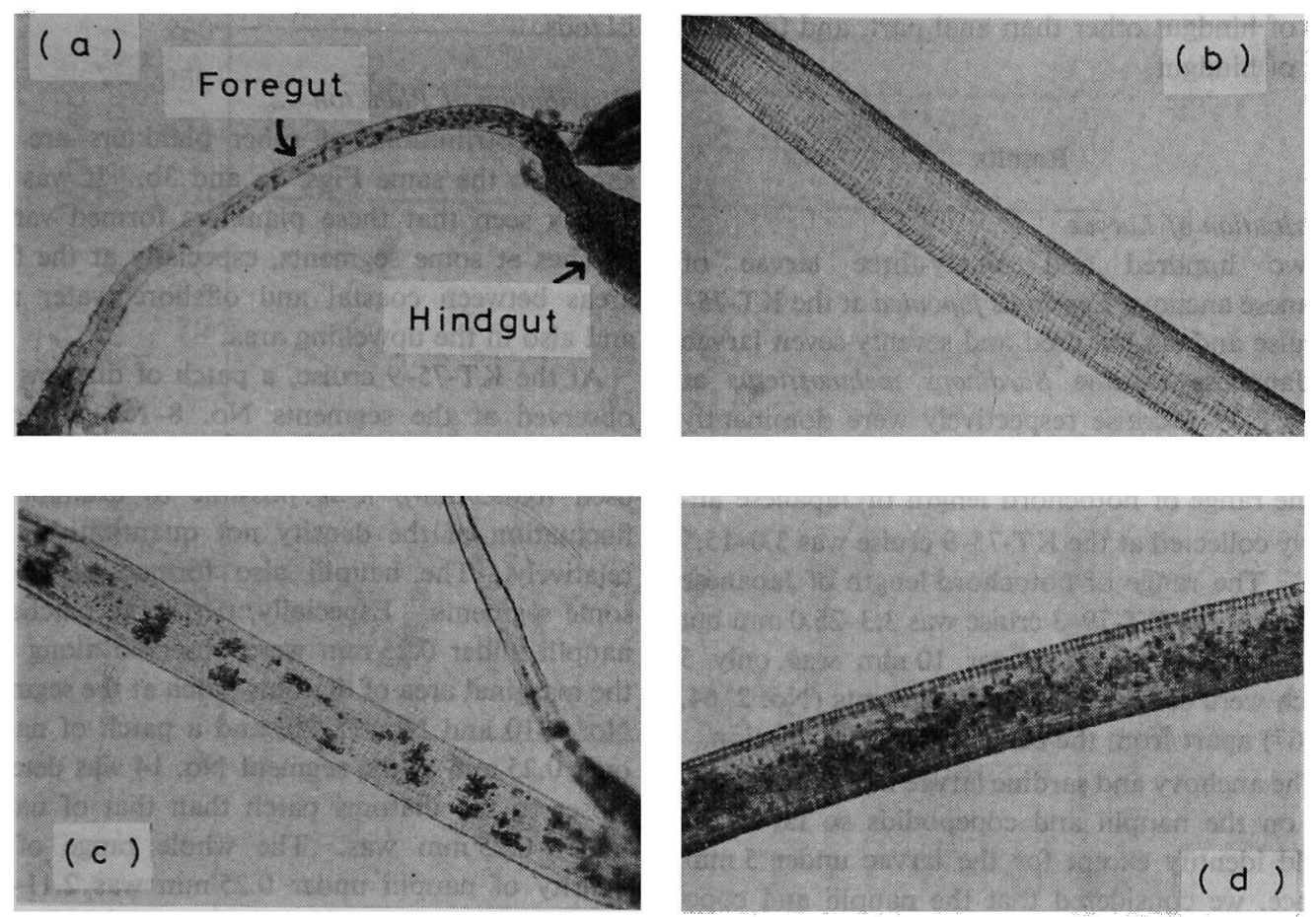

Fig. 2. Foreguts taken out from larval anchovy, (a) the foregut just taken out from the body, (b) entirely empty, (c) feeding, and (d) full foregut.

transect segment was about $3 \mathrm{~km}$ at the KT-75-9 cruise and $1.5 \mathrm{~km}$ (and $0.75 \mathrm{~km}$ ) at the KT-79-3 cruise. The ship's courses were nearly straight. The number of segments on survey lines was 32 at the KT-75-9 cruise and 72 at the KT-79-3 cruise.

The mesh size of filtering net used was XX13 $(0.095 \mathrm{~mm})$. The samples collected were washed down each time with same procedure. The samples were preserved in $5 \%$ neutralized formalin. Surface water temperature was measured by thermometer and autothermometer continuously in order to estimate the oceanographic structures.

\section{Sample Treatments}

The densities of food organisms, nauplii of each size and the others, were estimated by counting three times with Sedgwick-Rafter cell after concentrating the samples to adequate density by decantation.

Based on the observation of gut contents of Japanese anchovy larvae, Uotani et al. ${ }^{20)}$ reported that there was a strong correlation between the size of larvae and the food size irrespective of the species of food organisms. Judging from their observation, we considered the available food organisms of larvae of each size class as follows, larvae under $5 \mathrm{~mm}$ (Notochord Length) feed on only the nauplii under $0.25 \mathrm{~mm}$ (B.L.), the larvae of $5.1-10.0 \mathrm{~mm}$ feed on all nauplii and small copepodids under $0.5 \mathrm{~mm}$, and the larvae of 10.1$15.0 \mathrm{~mm}$ feed on the nauplii over $0.25 \mathrm{~mm}$ and copepodids under $1 \mathrm{~mm}$, and the larvae over 15 $\mathrm{mm}$ feed on all copepodids.

The feeding conditions of larvae at and prior to the sampling time were estimated through observation of the foreguts (this implies the foregut and midgut used by Miller et al. ${ }^{21}$ ) and hindguts of all larvae. They were taken out from the body by aid of two small needles. The occurrence of contents in their foreguts was examined under microscope without any incision as shown in Fig. 2. The foreguts of larvae under $25 \mathrm{~mm}$ were transparent and it was quite easy to confirm the existence of contents. Since it was difficult to distinguish contents in the hindguts from the tissue of the hindgut itself, the existence of contents was confirmed by movement of contents when pressing the hindgut with small needles. We considered any content in the gut as food organism.

In order to know the occurrence pattern of the food organisms in the gut, the occurrences of contents were recorded by the four parts (a-d), i.e., (a) foregut, (b) forepart of hindgut, (c) hind- 
part of hindgut other than anal part, and (d) anal part of hindgut.

\section{Results}

\section{Distribution of Larvae}

Two hundred and ninety-three larvae of Japanese anchovy Engraulis japonica at the KT-759 cruise and six hundred and seventy-seven larvae of Japanese sardine Sardinops melanostictus at the KT-79-3 cruise respectively were dominantly collected with a small number of other species.

The range of notochord length of Japanese anchovy collected at the KT-75-9 cruise was 3.0-15.5 $\mathrm{mm}$. The range of notochord length of Japanese sardine at the KT-79-3 cruise was $3.3-25.0 \mathrm{~mm}$ but the number of larvae under $10 \mathrm{~mm}$ was only 5 which were collected at some segments (No. 2, 64, $65,67)$ apart from the center of the distribution.

The anchovy and sardine larvae have dominantly fed on the nauplii and copepodids so far as we could identify except for the larvae under $5 \mathrm{~mm}$. Hence, we considered that the nauplii and copepodids were most important food organisms.

The distributions of Japanese anchovy and sardine larvae along the survey lines are shown in lower parts of Figs. $3 a$ and $3 b$ with open circles, respectively. It is clearly observed that there were some patches of larvae. Solid circles indicate the density of feeding larvae.

In the case of anchovy larvae, the peaks of patches of larvae of all size classes were coincidentally observed at the segments No. 18-20. From the whole pattern of distribution, however, the difference by size in the main area of distribution is clearly seen. The reason is considered that they were gradually drifted in succession from main spawning area by ocean current.

On the contrary, the patch of sardine larvae at the segments No. 30-36 was composed of all size classes. The patch of each size class was associated with the upwelling area caused by Izu Islands in Kuroshio Current. Then, it was presumed that they might have grown enough to be able to gather and/or they might have been concentrated to the area by ocean current.

Furthermore, a patch was observed in Kuroshio Current (at the segments No. 45-50) apart from the main patch around the islands. This patch was probably detached from the main patch, drifted and transported into Kuroshio Current, since the size composition of larvae in the patch was identical to that in the main patch around the islands.

\section{Distribution of Plankton}

The distributions of other plankters are also shown in the same Figs. $3 a$ and $3 b$. It was also clearly seen that these plankters formed various patches at some segments, especially at the front areas between coastal and offshore water mass and also in the upwelling area.

At the KT-75-9 cruise, a patch of diatoms was observed at the segments No. 8-15. Although the almost all diatoms pass through the mesh used $(0.095 \mathrm{~mm})$, it is possible to examine the fluctuation of the density not quantitatively but relatively. The nauplii also formed patches at some segments. Especially, two large patches of nauplii under $0.25 \mathrm{~mm}$ were observed along with the marginal area of diatoms patch at the segments No. 8-10 and No. 15-20, and a patch of nauplii over $0.25 \mathrm{~mm}$ at the segment No. 14 was detected closer to the diatoms patch than that of nauplii under $0.25 \mathrm{~mm}$ was. The whole range of the density of nauplii under $0.25 \mathrm{~mm}$ was $2.11-38.5$ individuals per liter with an average of 8.37 , and a standard deviation of 7.2.

At the KT-79-3 cruise, patches of Trichodesmium spp. were periodically detected (the average distance of the peaks of main patches was about $10.2 \mathrm{~km}$ ) with a gradual decrease of the peak densities. Two peaks were associated with the marginal area of upwelling at the segments Nos. 23 and 31, and a peak at the segment No. 47 was concided with marginal area of the detached patch of sardine larvae at the segments No. 46-47 in Kuroshio Current.

A high density area of diatoms was observed at the front of the coastal water at the segments No. $63-72$, and its density abruptly decreased in offshore area. Two patches were respectively coincided with the upwelling area and the detached patch of larvae at the segments No. 18-24 and No. 46-50.

Nauplii under $0.25 \mathrm{~mm}$ formed a patch at the segments No. 62-64 in the marginal area of the diatoms patch with its peak density of 46.6 individuals per liter. A patch of nauplii over 0.25 $\mathrm{mm}$ was observed at the segments No. 63-66 closer to the diatoms patch than the patch of nauplii under $0.25 \mathrm{~mm}$ was. The range of the density of nauplii under $0.25 \mathrm{~mm}$ was $1.1-46.6$ individuals per liter with an average of 8.56 , and a standard deviation of 6.99 .

This observed level of nauplii was quite low 

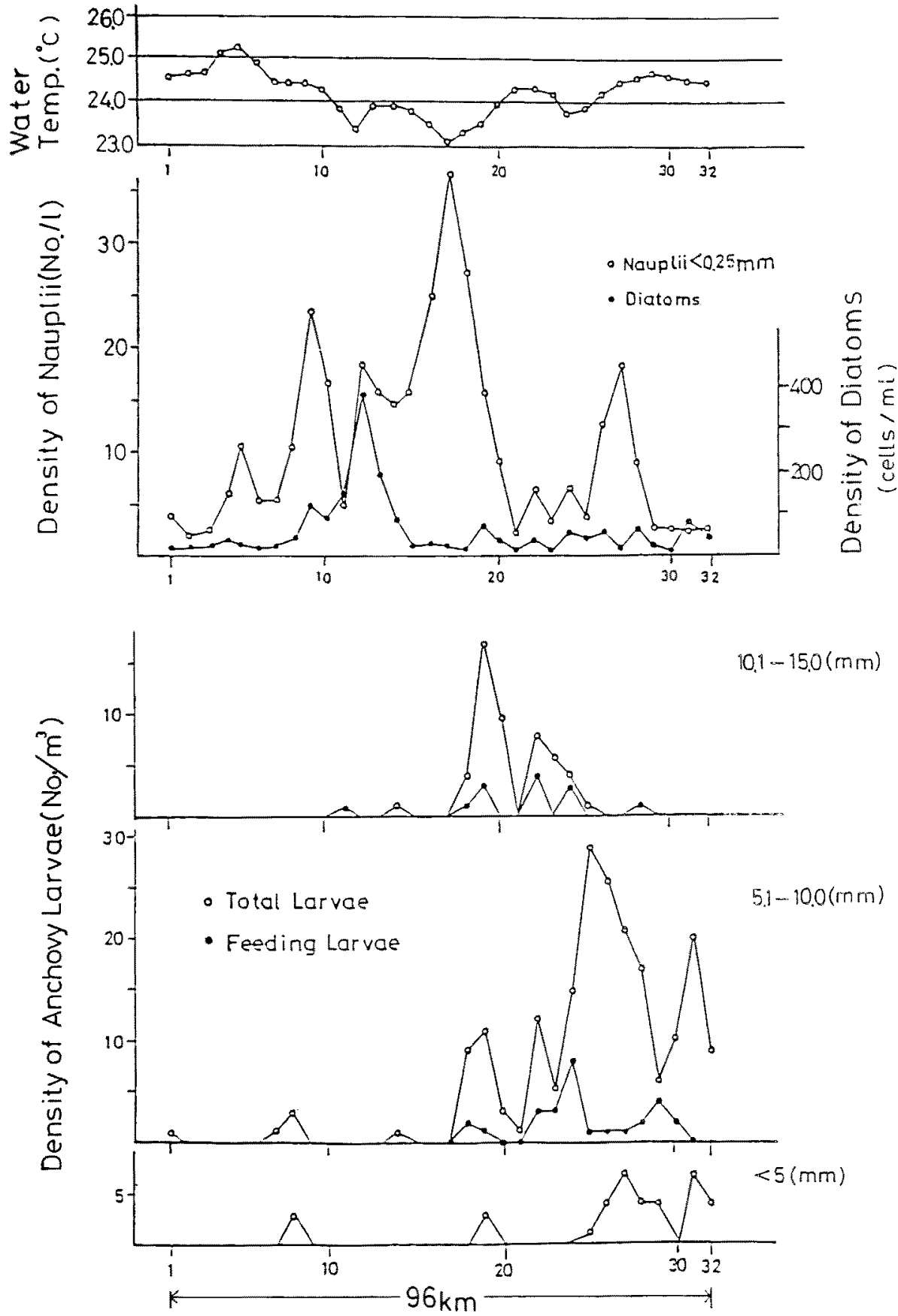

Number of Segment

(a)

Fig. 3a, b. (a) The distributions of each size class larvae of anchovy and plankters along the transect line of KT-75-9 cruise. (b) The distributions of each size class larvae of sardine and plankters along the transect line of KT-79-3 cruise.

The density of feeding larvae are represented by solid circles, and the density of total larvae are represented by open circles.

Temperature and the length of transect lines are shown in upper and lower parts respectively. 


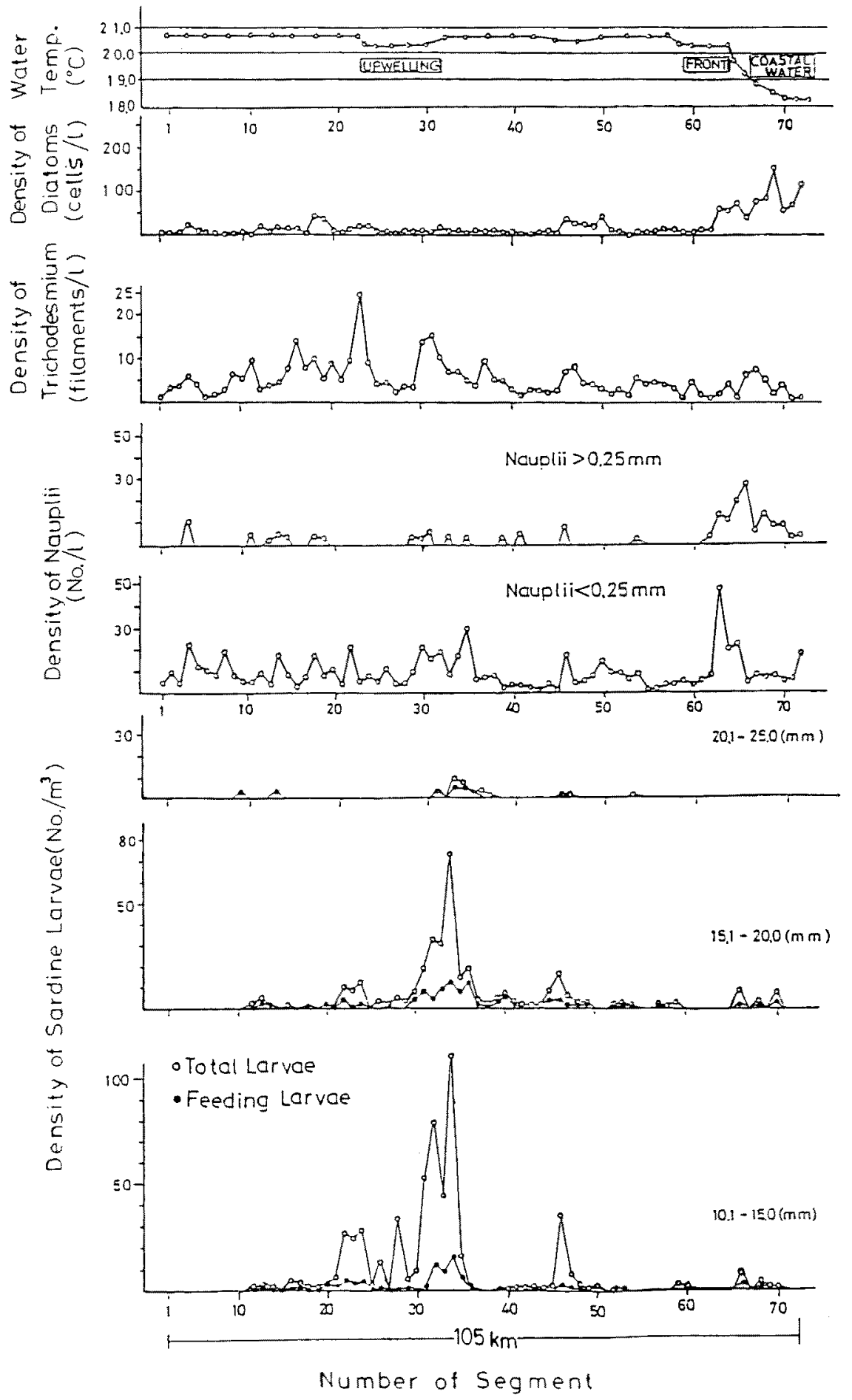

(b) 
Table 2. The results of the occurrence of the food organisms in the four parts of guts of the Japanese anchovy and sardine

\begin{tabular}{|c|c|c|c|c|c|c|c|c|}
\hline \multicolumn{9}{|c|}{ Anchovy } \\
\hline \multicolumn{4}{|c|}{$\begin{array}{c}\text { Incidence of contents } \\
\text { in }\end{array}$} & \multicolumn{5}{|c|}{ The range of body length (N. L. in mm) } \\
\hline $\begin{array}{l}\text { Foregut } \\
\text { (a) }\end{array}$ & (b) & $\begin{array}{l}\text { Hindgut } \\
\text { (c) }\end{array}$ & (d) & $\leqq 5.0$ & $5.1-10.0$ & $10.1-15.0$ & $15.1-20.0$ & $<20.0$ \\
\hline+ & + & + & + & 0 & 14 & 5 & 1 & 0 \\
\hline+ & - & + & + & 0 & 5 & 0 & 0 & 0 \\
\hline+ & + & - & + & 0 & 6 & 4 & 0 & 0 \\
\hline+ & + & + & - & 0 & 3 & 3 & 0 & 0 \\
\hline+ & - & - & + & 0 & 13 & 1 & 0 & 0 \\
\hline+ & - & + & - & 1 & 3 & 0 & 0 & 0 \\
\hline+ & + & - & - & 0 & 1 & 0 & 0 & 0 \\
\hline+ & - & - & - & 1 & 2 & 0 & 0 & 0 \\
\hline- & + & + & + & 0 & 0 & 0 & 0 & 0 \\
\hline - & - & + & + & 2 & 6 & 5 & 0 & 0 \\
\hline- & + & - & + & 0 & 3 & 2 & 0 & 0 \\
\hline - & + & + & - & 0 & 1 & 0 & 0 & 0 \\
\hline- & - & - & + & 3 & 43 & 12 & 1 & 0 \\
\hline- & - & + & - & 2 & 14 & 2 & 1 & 0 \\
\hline- & + & - & - & 1 & 0 & 0 & 0 & 0 \\
\hline- & - & - & - & 30 & 87 & 15 & 0 & 0 \\
\hline
\end{tabular}

\begin{tabular}{|c|c|c|c|c|c|c|c|c|}
\hline \multicolumn{9}{|c|}{ Sardine } \\
\hline \multicolumn{4}{|c|}{$\begin{array}{l}\text { Incidence of contents } \\
\text { in }\end{array}$} & \multicolumn{5}{|c|}{ The range of body length (N. L. in mm) } \\
\hline $\begin{array}{l}\text { Foregut } \\
\text { (a) }\end{array}$ & (b) & $\begin{array}{l}\text { Hindgut } \\
\text { (c) }\end{array}$ & (d) & $\leqq 5.0$ & $5.1-10.0$ & $10.1-15.0$ & $15.1-20.0$ & $<20.0$ \\
\hline+ & + & + & + & 0 & 0 & 42 & 55 & 14 \\
\hline+ & - & + & + & 0 & 0 & 8 & 7 & 0 \\
\hline+ & + & - & + & 0 & 0 & 5 & 4 & 0 \\
\hline+ & + & + & - & 0 & 0 & 4 & 6 & 0 \\
\hline+ & - & - & + & 0 & 0 & 11 & 2 & 1 \\
\hline+ & - & + & - & 0 & 0 & 1 & 3 & 0 \\
\hline+ & + & - & - & 0 & 0 & 2 & 0 & 0 \\
\hline+ & - & - & - & 0 & 1 & 4 & 0 & 0 \\
\hline- & + & + & + & 0 & 0 & 4 & 4 & 2 \\
\hline- & - & + & + & 0 & 0 & 29 & 24 & 3 \\
\hline- & + & - & + & 0 & 0 & 12 & 8 & 1 \\
\hline- & + & + & - & 0 & 0 & 6 & 7 & 0 \\
\hline- & - & - & + & 0 & 0 & 90 & 48 & 1 \\
\hline- & - & + & - & 0 & 0 & 24 & 5 & 0 \\
\hline- & + & - & - & 0 & 0 & 11 & 8 & 0 \\
\hline- & - & - & - & 1 & 3 & 172 & 44 & 0 \\
\hline
\end{tabular}

compared to the threshold food density for survival estimated by rearing experiments. This suggests that the food organisms were too sparse for early larvae to survive in these surveyed areas.

Some patches of food organisms occasionally appeared at the same area with larval patches, and at KT-75-9 cruise, the patch of anchovy larvae of larger size occurred closer to the waters where the patch of nauplii occurred. Generally speaking, however, the results of our surveys show that patches of larvae rarely concided with those of food organisms. Larvae did hardly encounter with abundant food organisms in the sea.

\section{Index of Feeding Larvae}

Sixteenth occurrence patterns of the food organisms in the guts of the larvae by size class are indicated in Table 2. Of the larvae, which had some food organisms in the foregut, almost all had also contents in the three parts of the hindgut. 


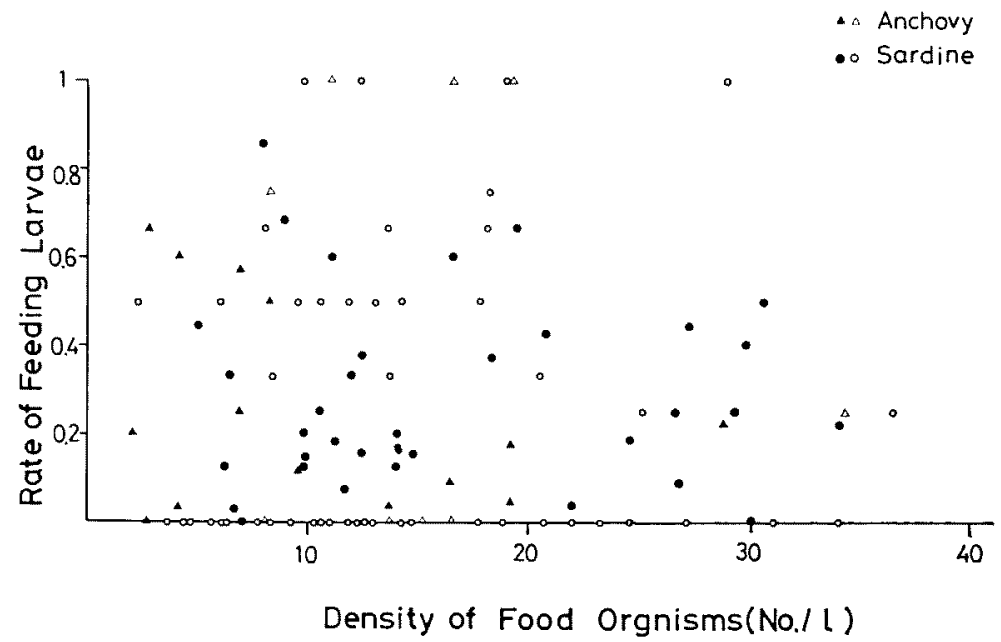

Fig. 4. The relationship of the rate of feeding larvae of each size class and the density of the edible size food organisms at each segment.

Solid circles and triangles show the case of the number of anchovy and sardine larvae examined more than 5 respectively.

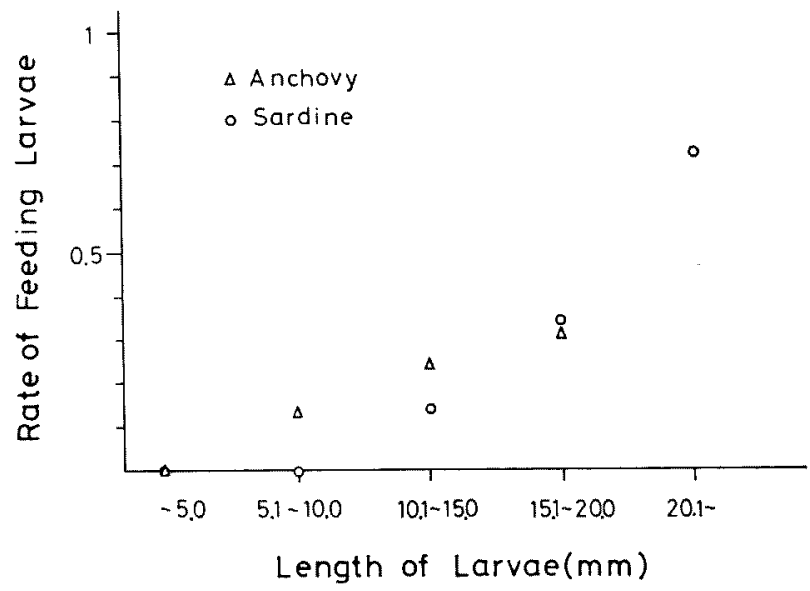

Fig. 5. The relationship of the rate of feeding larvae and the larval notochord length class.

It is considered that these larvae have fed actively at and prior to sampling time. On the contrary, almost all of the larvae which had not any food organism in the foregut had neither in the hindgut and only a few had some in the anal part (d). The food organisms at the anal part should have been fed by the larvae some time before the sampling time. It seems adequate to take the existence of contents in the foregut as an index of "feeding".

Chitty, ${ }^{22}$ however, reported that the food organisms travelled rapidly down the foregut and entered into the hindgut $(0.5-2.0 \mathrm{sec}$.). We yet recognized nauplii, the spines of nauplii and copepodids, and some crashed matters in the foreguts as shown in Fig. 2. We considered that these contents in the foreguts are (1) food organisms in the case of fullgut, (2) leftovers of food organisms already passed through the foregut, (3) food organisms flowed back into the foregut from the hindgut at sampling and fixation, and (4) food organisms just fed in the net at the sampling. From these views, the existence of the contents in the foregut may not be an adequate index of "feeding" in some cases.

We consider that the survival potential of the larvae is determined by constant and sufficient feeding since they must spend much energy to search and catch food. Therefore, we need an index which indicate constant and sufficient feeding. Hence, we defined the feeding larvae which 


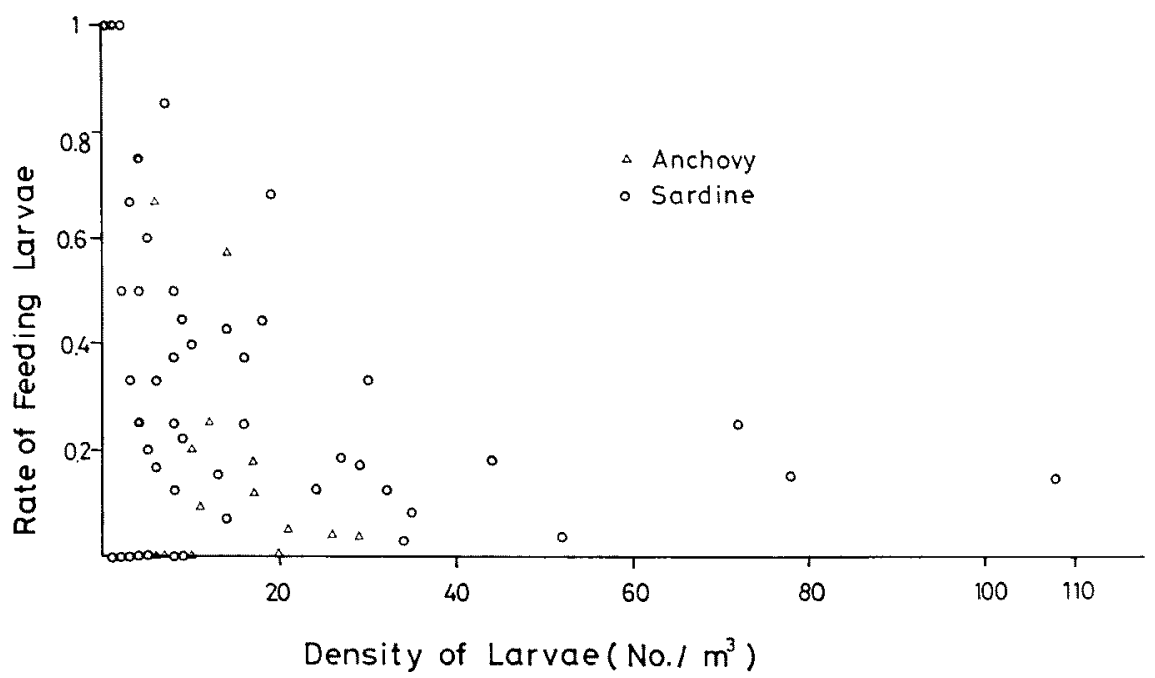

Fig. 6. The relationship of the rate of feeding larvae and the larval density at each segment.

had some contents in the gut more than three parts. The rate of feeding larvae to the total larvae collected was calculated by segment and by size class of larva to represent the average feeding conditions at each segment in the sea.

\section{Rate of Feeding Larvae}

The percentages of feeding larvae of anchovy and sardine were $14.0 \%$ and $22.9 \%$ respectively. The percentages of larvae which had not any content in the gut were $45.1 \%$ of anchovy and $33.0 \%$ of sardine. Concerning to the foregut only, however, the percentages of larvae having relatively large amount food organisms, i.e. the number of particles of food organisms in the foregut was more than 10 (Fig. 2 (c)), were only $4.1 \%$ of anchovy and $2.7 \%$ of sardine larvae. Furthermore, the larvae with full foregut (Fig. 2 (d)) were only two, $11.2 \mathrm{~mm}$ anchovy larva at the segment No. 22 and $21.5 \mathrm{~mm}$ sardine larva at the segment No. 13.

The relation between the rate of feeding larvae and the density of their food organisms at each segment is shown in Fig. 4. The rates of feeding anchovy and sardine larvae are indicated with solid triangles and circles respectively in the case the number of larvae measured at one segment was more than 5 , and the open triangles and circles indicate that the measured number was less than 4. In Fig. 4, although there seems to be a negative correlation between the rate of feeding larvae and the density of food organisms, it is better to say rather difficult to find any relationship.

The relation between the rate of feeding larvae and their notochord length is shown in Fig. 5.
The rate of feeding larvae over $20 \mathrm{~mm}$ is very high, and the rate of feeding larvae of under $5 \mathrm{~mm}$ was extremely low.

The relation between the rate of feeding larvae and the density of larvae is shown in Fig. 6. The rate of feeding larvae clearly decreased with the increase of the density of larvae. This result might be influenced by the size composition of larvae, since the larvae at high larval density areas were mainly composed of smaller length ones with low rate of feeding. However, the high rates of feeding larvae at low larval density were not influenced by size composition. Furthermore, it is also seen in Figs. $3 a$ and $3 b$ that the density of feeding larvae, which are indicated solid circles, did not increase in proportion to the increase of the density of total larvae.

\section{Discussion}

The larvae and food organisms were distributed in patchiness. And, the formation of patches were related to the various oceanographic structures. Especially, the upwelling and front were important in th formations of various patches. These upwelling and front are generated by the contact of different water masses and are characterized by high turbulence of water.

There are many reports concerning to the relations between the zoo- and phyto-plankton patches and the oceanographic structures. ${ }^{29-30)}$ From these reports along with our results, it can be said that the oceanographic structures largely influence on the distribution of various plankton organisms including fish larvae and make an 
essential factor on examining the mechanism of stock fluctuation of marine fish.

In this survey, detached patches of larvae and other plankters were observed in Kuroshio Current. It was considered that the patches were taken in the eddy, which might be resulted by the islands, and detached and transported into Kuroshio Current. Uda and Ishino ${ }^{31)}$ and Hamner and Hauri ${ }^{3: 2}$ indicated the existence of eddies and patches of various plankters behind islands in the ocean current. Shelton and Hutchings ${ }^{39}$ observed that patches of anchovy eggs and larvae in the low productivity area were transported by the frontal jet current which generated along the continental shelf margin, and that the intake mechanisms were greatly influenced by wind conditions. It is also considered that the detached patches observed in our survey are separated from the main patch and transported by Kuroshio Current with the eddy caused by islands. This is an important phenomenon in examining the recruitment mechanism of larvae.

Lasker et al $^{34)}$ reported that the dinofiagellate Gymnodinium splendens has an important role for survival of first feeding larvae of northern anchovy Engraulis mordax. Japanese anchovy and sardine larvae also may utilize these organisms but we have not obtained any evidence in this survey and have not known until now any positive report on the utilization of the dinoflagellates and other phyto-plankters $^{35}$ ) as larval food for Japanese anchovy and sardine. Hence, we considered that the densities of nauplii and copepodids are the most important index of the food density of the larvae in this survey.

Since the gut contents of the larvae less than $5 \mathrm{~mm}$ could not be positively identified even at family level, we only examined if the larvae have a content or not in the gut. This confirmation of existence and absence of gut contents was carried out easily. Next, we define the larvae, which have some contents in the gut more than three parts, as "feeding larvae". Concerning to the purpose of present paper, this definition could be used certain degree enough to represent the larval feeding condition with regard to further survival potential in the sea at the sampling time. Because we consider that the most important is to know that the larvae were able or not able to take up continuously the exogenous nutrient for survival.

At first, we expected that if the average food density of a segment is high, the rate of feeding larvae may be higher than that at low food density. However, the result of this survey was against our expectation and any relationship between rate of feeding larvae and food density was not recognized (Fig. 4).

Probably, two reasons can be given. Firstly, micro-scale patches of food organisms might influence. $\left.{ }^{2}{ }^{7}\right)$ That is to say, though the average density of food organisms at a segment was low, there might exist minute spheres of high food density (micro-patch), and some "lucky" larvae could encounter to them and were able to feed. Secondly, we can suppose that some "tough" larvae could feed even in low density of food organisms, but the other larvae could not feed even in high density. This implies that the individual ability of feeding determines the fate of the larva itself.

The rate of feeding larvae at high larval density areas, such as, at the peaks of the patch of larvae, was low comparing to that at low larval density areas. O'Connel ${ }^{3 \theta)}$ showed that the percentage of the starved larvae in the sea was higher at the stations of high larval density (=patch) and that the patches were formed under the fluctuating environmental conditions.

We presume the reason of inverse-correlation is that the number of micro-patch and its detection by larvae are limited in a segment, and/or that larvae can not eat in spite of sufficient food organisms due to high speed of food organisms passing through the field of vision of larvae. Because it is expected that the turbulence caused by the accumulative action of water may be high at the center of the patch.

It was reported by Houde $^{37}$ ) that the larvae reared in low larval density had survived even at so low food density that was not enough to survive in high larval density. Though even the lowest density of larvae of his rearing experiment was higher comparing to the density of larvae in the sea, it may be an important clue concerning to larval survival in the sea of low food density. However, in order to interprete these phenomena with regard to survival mechanism, it is necessary know about larval and food organisms' patchiness and the feeding behavior in the scale of visible sphere of larvae.

Next, almost all of the larvae under $5 \mathrm{~mm}$ did not feed and the rate of feeding larvae increased with growth. Therefore, it is presumed that the feeding success at an earlier stage is important to determine the number of recruit since the varia- 
tion of feeding success is most effective when the number of larvae is large.

But, it is necessary to survey and analyze statistically various pattern of patches in order to make clear the influence of patchiness on larval survival and recruitment.

\section{Acknowledgements}

We express our sincere thanks to officers and crew of the R/V "Tansei-maru" for their helpful assistance during the surveys and experiments.

This study was supported in part by Grant-inAid for Encouragement of Young Scientist from the Ministry of Education of Japan.

\section{References}

1) J. Hjort: Rapp. P.-V. Réun. Cons. int. Explor. Mer, 20, 1-228 (1914).

2) C. P. O'Connel and L. P. Raymond: J. Exp. Mar. Biol. Ecol., 5, 187-191 (1970).

3) V.P. Saksena and E. D. Houde: J. Exp. Mar. Biol. Ecol., 8, 249-258 (1972).

4) E. D. Houde: Bull. Mar. Sci., 28, 395-411 (1978).

5) R. Larker: Fish. Bull., 73, 453-462 (1975).

6) R. Lasker: Rapp. P.-V. Réun. Cons. int. Explor. Mer, 178, 375-388 (1981).

7) J. E. Shelbourne: J. Mar. Biol. Ass. U. K., 36, 539-522 (1957).

8) J. R. Hunter and G. L. Thomas: in "The Early Life Histry of Fish" (ed. by J.H.S. Blaxter), Springer-Verlag, 1974, pp. 559-574.

9) G. C. Laurence: J. Fish. Res. Bd. Can., 31, 14151419 (1974).

10) A. C. Hardy: Discovery Reports, 11, 475-510 (1936).

11) R. M. Cassie: N. Z. J. Sci., 2, 339-365 (1959).

12) D. H. Cushing: Rapp. P.-V. Réun. Cons. int. Explor. Mer, 153, 152-164 (1962).

13) M. Anraku: Bull. Plankton Soc. Japan, 22, 1726 (1975).

14) J. M. Miller: Limnol. Oceanogr., 18, 175-178 (1973).

15) J. L. Star and M. M. Mullin: Deep-Sea Res., 28A, 1303-1322 (1981).

16) K. Matsushita, M. Shimizu, and Y. Nose:
Nippon Suisan Gakkaishi, 48, 355-362 (1982).

17) Y. Kiyono and T. Hirano: Marine Sciencel Monthly, 178, 34-40 (1978).

18) Agri. Fore. Fish. Res. Council: "Reports of propulsion council of co-operative research concerning to the fishery dynamics" translated from Japanese, Tokyo, 1961, pp. 102-121.

19) K. Matsushita, M. Shimizu, and Y. Nose: Nippon Suisan Gakkaishi, 32, 155-168 (1985).

20) I. Uotani, A. Izuha, and K. Asai: Nippon Suisan Gakkaishi, 44, 427-434 (1978).

21) J. M. Miller, W. Watoson, and J. M. Leis: An Atlas of Common Near-shore Marine Fish Larvae of the Hawaiian Islands, University of Hawaii Sea Grant College Program, Honolulu, 1979, p. 5.

22) N. Chitty: Rapp. P.-v. Réun. Cons. int. Explor. Mer, 178, 320-321 (1981).

23) H. H. Seliger, J. H. Carpenter, M. Loftus, and W. D. McElroy: Limnol. Oceanogr., 15, 234 245 (1970).

24) H. H. Seliger, K. R. Mckinley, W. H. Biggly, R. B. Rivkin, and K. R. H. Aspden: Mar. Biol., 61, 119-131 (1981).

25) D. J. Tranter, G. S. Leech, and D. Airey: Aust. J. Mar. Freshw. Res., 34, 665-680 (1983).

26) J. A. Yoder and L. P. Atkinson: Limnol. Oceanogr., 26, 1103-1110 (1981).

27) S. Ishizaka and M. Takahashi: Bull. Coastal Oceanogr., 21, 148-155 (1984).

28) I. Hamann, H. Ch. John, and E. Mittelstaedt: Deep-Sea Res., 28A, 561-515 (1981).

29) K. Kuroda, T. Kidachi, A. Tomosada, and K. Segawa: Bull. Tokai Reg. Fish. Res. Lab., No. 115, 47-64 (1985).

30) K. Kuroda: Bull. Tokai Reg. Fish. Res. Lab., No. 119, 109-122 (1986).

31) M. Uda and M. Ishino: J. Tokyo Univ. Fish., 44, 105-129 (1958).

32) W. M. Hamner and I. R. Hauri: Limnol. Oceanogr., 26, 1084-1102 (1981).

33) P. A. Shelton and L. Hutchings: J. Cons, int. Explor. Mer, 40, 185-193 (1982).

34) R. Lasker, H. M. Feder, G. H. Theilacker, and R. C. May: Mar. Biol., 5, 345-353 (1970).

35) E. D. Scura and C.W. Jerde: Fish. Bull., 75, 577-583 (1977).

36) C. P. O'Connel: Fish. Bull., 78, 475-489 (1980).

37) E. D. Houde: J. Fish Biol., 7, 115-127 (1975). 